\title{
Spatiotemporal variation of the epifaunal assemblages associated to Sargassum muticum on the NW Atlantic coast of Morocco
}

\author{
Zahira Belattmania $^{1}$ (D) Abdellatif Chaouti $^{1}$ - Aschwin H. Engelen ${ }^{2} \cdot$ Ester A. Serrao $^{2} \cdot$ Margarida Machado $^{2}$. \\ Abdeltif Reani $^{1} \cdot$ Brahim Sabour $^{1}$
}

Received: 28 October 2019 / Accepted: 22 June 2020

(C) Springer-Verlag GmbH Germany, part of Springer Nature 2020

\begin{abstract}
Epifaunal assemblages inhabiting the non-indigenous macroalga Sargassum muticum (Yendo) Fensholt were investigated on two physically distinct intertidal rocky (S1) and sandy (S2) sites along the Atlantic coast of Morocco. The objective of this study was to test whether the habitat-forming marine alga $S$. muticum invasive in these sites supported different epifaunal assemblages under different environmental conditions and through time. The gastropods Steromphala umbilicalis, S. pennanti, and Rissoa parva and the isopod Dynamene bidentata were the most contributive species to the dissimilarity of epifaunal assemblage structure between both sites throughout seasons. SIMPER analysis showed a dissimilarity of $58.3-78.5 \%$ in the associated species composition of S. muticum between study sites with respect to sampling season. Species diversity and total abundance were significantly higher at the rocky site compared to the sandy site. PERMANOVA analyses showed significant differences of associated epifaunal assemblage structure for the season and site interaction. Accordingly, site and season were determinant factors conditioning the role of habitat in structuring epifaunal assemblages.
\end{abstract}

Keywords Sargassum muticum · Associated epifauna · Variability · Interactions · Environmental conditions · Substrate · Intertidal $\cdot$ Atlantic shores $\cdot$ Morocco

\section{Introduction}

Marine macroalgae can be relevant as biogenic structures. They are known among the true autigenic epibenthic ecosystem engineers and some species are referred to as "foundation species" that have strong effects on local community structure through the mechanisms of environment stabilization, provision of critical food resources, and/or creation of biogenic habitat (Ellison et al. 2005; Jones and Thornber 2010; Ramus et al. 2017; Metzger et al. 2019). Marine macroalgae perform various functions and have a major effect on the

Responsible editor: Philippe Garrigues

Zahira Belattmania belattmania.z@ucd.ac.ma

1 Research Unit "Phycology, Blue Biodiversity and Biotechnology," Department of Biology, Faculty of Sciences, University of Chouaib Doukkali, El Jadida, Morocco

2 CCMAR - Centre of Marine Sciences, University of Algarve, Faro, Portugal structure of marine communities (Stachowicz 2001; Cacabelos et al. 2010). They offer refuge from predation and competition (Ware et al. 2019). They provide shelter and food (generating in situ detritus and nutrients after decomposition) and spawning and nursery grounds for many organisms, especially the earliest life stages (Buschmann 1990; Taylor 1998; Fredriksen et al. 2005). They increase space for settlement and protect the organisms from physical stress including wave action, heat, and desiccation (Hicks 1980; Wikström and Kautsky 2004; Cacabelos et al. 2010). They may modify the hydrodynamism near the sea floor, with potentially significant ecological effects on sedimentation.

Interactions between macroalgae and their associated fauna can be influenced by physical (i.e., wave action, aerial exposure, irradiance, temperature ranges and time available for nutrient exchange, accumulation of sediments, and desiccation) and biological (i.e., grazing) factors (Bertness et al. 1999; Mueller et al. 2015; Umanzor et al. 2017). Macrobenthic fauna distribution patterns are eventually the result of a complex interaction of various processes operating both within the water column as well as the sedimentary environment (Bolam et al. 2008). At large spatial scales for 
example, gradients such as temperature, salinity, and depth generally produce changes in species distributions and in structure, organization, and functioning of the assemblage, while changes in habitat characteristics (e.g., sediment granulometry, and type of substratum) are thought to greatly influence assemblage structure at more local scales (Gray 2001; Giberto et al. 2004; Bremner et al. 2006; Labrune et al. 2007). Spatial variability of epifaunal assemblages among and within habitats may be shaped by temporal variation at different scales ranging from weeks to months (Taylor 1998; Cacabelos et al. 2010; Jones and Thornber 2010). On a similar line, modifications in coastal habitat-forming macroalgae might induce changes in the abundance, richness, or composition of faunal assemblages, and consequently may have great repercussions on the ecosystems (Engelen et al. 2013).

The introduction of non-indigenous macroalgae causes many serious ecological impacts affecting native marine communities, eroding biodiversity and modifying and/or disrupting the normal functioning of ecosystems (Schaffelke and Hewitt 2007; Bedini et al. 2015; Smith 2016). However, in some cases, the effects are not detectable or even positive (Thomsen 2010; Guerra-García et al. 2012; Thomsen et al. 2013). For example, some invasive habitat formers may be considered as sources of valuable ecosystem functions where native foundation species have been lost (Ramus et al. 2017).

Sargassum muticum (Yendo) Fensholt is a habitat-forming brown alga native from south-east Asia and recorded in Morocco since 2011 (Sabour et al. 2013). However, it has received very little attention despite being common in rocky intertidal habitats in the region of El Jadida (Belattmania et al. 2018a, b). S. muticum thalli can grow to lengths of up to $5 \mathrm{~m}$ (Sabour et al. 2013), and they are composed of two distinct parts: a perennial part, which contains the holdfast and one or more short main axes; and an annual part, consisting of variably sized secondary axes. S. muticum has a pseudo-perennial life cycle comprising a winter phase with a moderate growth rate and a faster growth phase during spring (Wernberg et al. 2004).

This algal species has been introduced in Europe in the early 1970 s and is currently widespread in numerous regions worldwide (Engelen et al. 2015). S. muticum has many characteristics that make it a successful invader, including high growth rates; rapid colonization of space; tolerance to temperatures between $-1{ }^{\circ} \mathrm{C}$ and $30{ }^{\circ} \mathrm{C}$ and survival in salinities below $10 \%$; high photosynthetic rates; copious reproduction, including asexual and self-fertilization strategies and efficient multiple dispersal mechanisms due to floating and drifting fertile thalli; and high habitat complexity (Norton 1976, 1977a, b; Critchley 1983; Hales and Fletcher 1989; Viejo 1997). The low tolerance of $S$. muticum to desiccation precludes colonization of regularly emerged littoral areas (Norton 1977a). The optimal tidal zone for S. muticum establishment is the extreme lower shore and shallow sublittoral fringe (Harries et al. 2007). S. muticum rarely occurs deeper than a few meters and the subtidal range is thought to be linked to water clarity and the availability of sufficient light for growth (Norton 1977a; Thomsen et al. 2006). Strong wave action induces the plant breakage and fragmentation, and populations are unable to establish in wave-exposed locations (Viejo et al. 1995). Thus, S. muticum colonizes mainly the sheltered shores where it often forms dense monospecific beds, whereas it is largely restricted to rock pools on exposed shores (Critchley 1983; Critchley et al. 1983; Fernández et al. 1990; Andrew and Viejo 1998a, b; Harries et al. 2007). S. muticum can establish on a variety of substrata, including bedrock to pebbles, shell fragments scattered on the sediment surface (Harries et al. 2007), wood, mooring lines, and wharves (Curiel et al. 1998) that provide an attachment point for the holdfast.

The present work aims at (i) identifying the main environmental drivers shaping spatial dynamics of the nonindigenous brown alga $S$. muticum along the El Jadida shoreline (northwestern Atlantic coast of Morocco); (ii) discussing about the observed distribution patterns of macro-epifauna associated with this habitat-forming macroalga; (iii) exploring potential differences of associated epifaunal assemblages between sandy and rocky intertidal sites situated at different elevations and also differing for substrate, hydrodynamics, and exposition; and (iv) raising hypotheses to explain the question whether S. muticum-associated epifauna assemblages between two intertidal sites under dissimilar environmental conditions are distinct and their differences would be reflected in differences in diversity, abundance, and taxonomic composition, and whether site and season influence the structure of these communities.

\section{Material and methods}

\section{Study areas}

The sampling sites (S1 and S2) are located along the El Jadida shoreline on the northwestern Atlantic coast of Morocco (Fig. 1). In this area, the tide is semidiurnal with an average period of around $745 \mathrm{~min}$ ( $12 \mathrm{~h}$ and $25 \mathrm{~min}$ ) and defined by a semidiurnal tidal cycle, consisting of two high and two low tides of different entity. The average tide amplitude is $4 \mathrm{~m}$ during spring tides and $2 \mathrm{~m}$ for neap tides. The Moroccan Atlantic coast is generally exposed to a strong energy characterized by swells from the north Atlantic mainly of west to northwest origin, but the most dominant swells are those of the north-northwest and north-eastern dial west. The first site S1 $\left(33^{\circ} 14^{\prime} 47.5^{\prime \prime} \mathrm{N} ; 8^{\circ} 32^{\prime} 31.9^{\prime \prime} \mathrm{W}\right)$ oriented north-westward is a fully wave-exposed coastal area. The S1 consists of an intertidal platform of rocky substratum (bedrock) with a marked roughness and sheltered shallow areas protected against the strong wave action by artificial reefs called "Bechkiras" 
Fig. 1 Geographical position and location of sampling sites (S1 and S2)

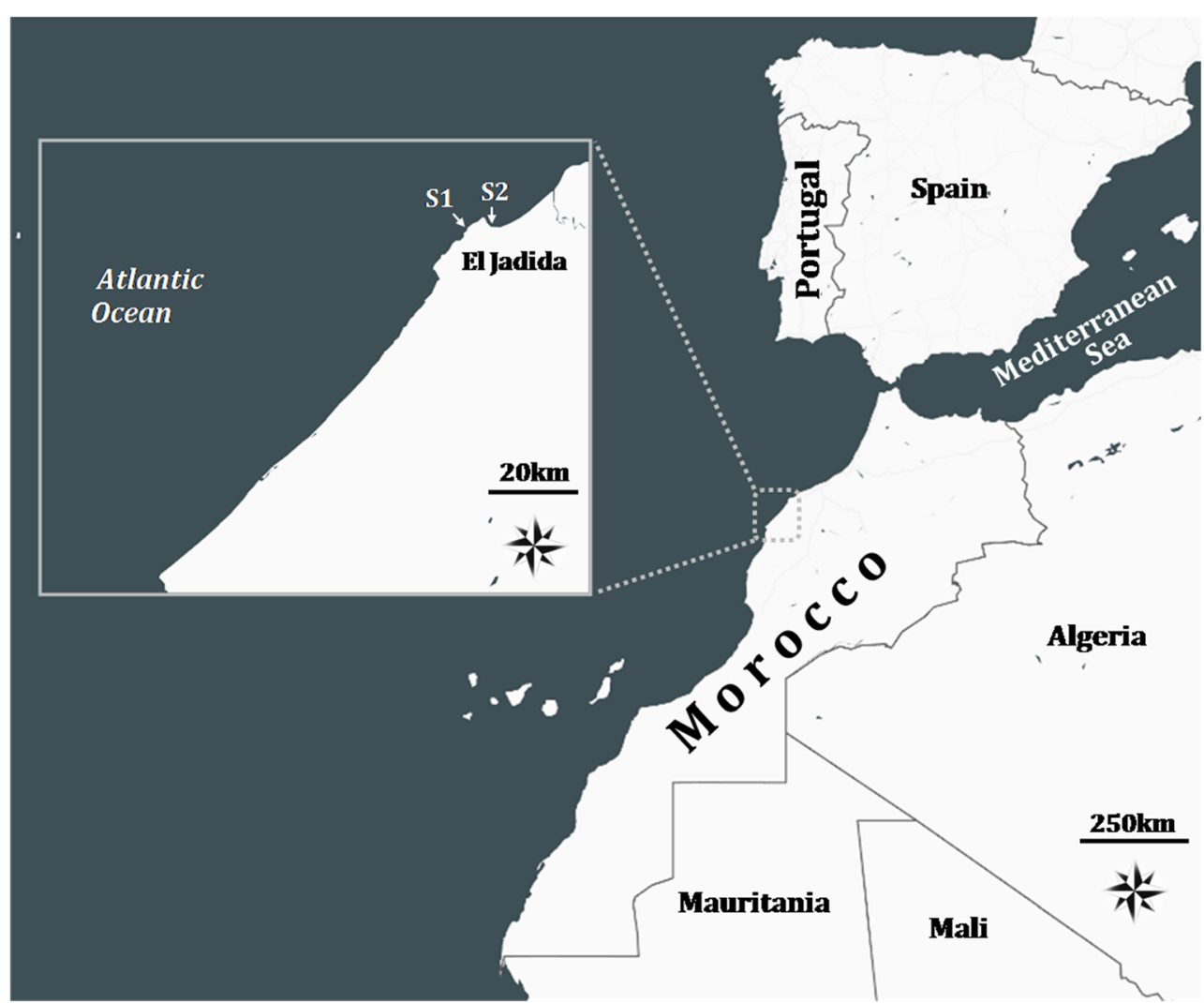

(Fig. 2a). These rockpools host a diverse macroalgal community (intermixed species) dominated by the invasive S. muticum showing persistent, dense, and extensive canopy, especially during periods of optimal growth. The second site
$\mathrm{S} 2\left(33^{\circ} 15^{\prime} 11.5^{\prime \prime} \mathrm{N} ; 8^{\circ} 29^{\prime} 54.1^{\prime \prime} \mathrm{W}\right)$ facing northeast is moderately protected from the wave action. The $\mathrm{S} 2$ consists of a sandy beach with shallow intertidal soft bottoms and few patches of outcroppping rocks providing hard substrates. In

a Ocean

S1

Littoral
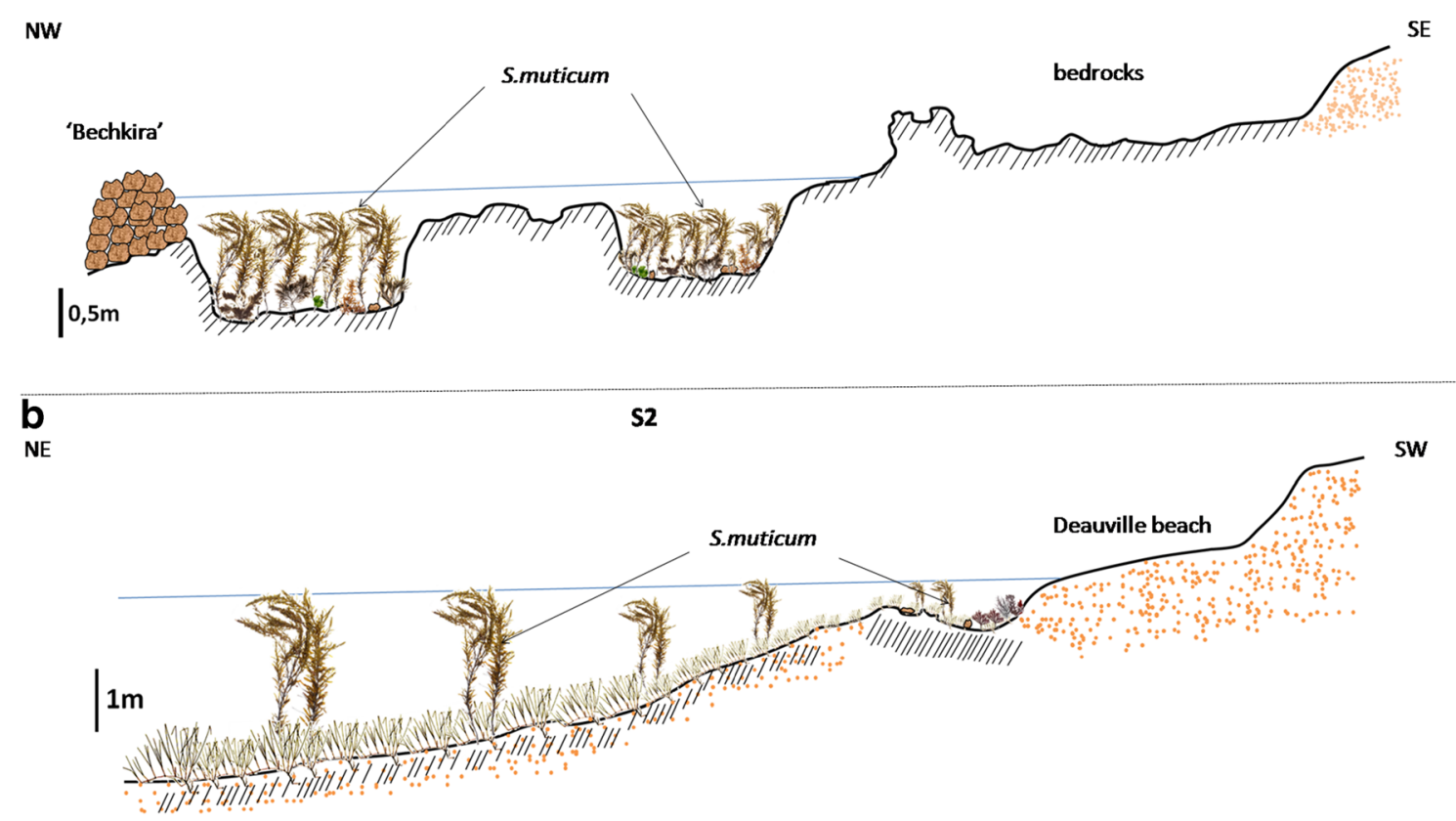

Fig. 2 Intertidal area profile in sites S1 (a) and S2 (b) with a schematic illustration of Sargassum muticum thalli 
this area, S. muticum thalli are restricted to bedrock covered by sand and they constitute scattered stands with large thalli constantly submerged by a body of water whose depth at low tide always exceeds $1 \mathrm{~m}$ (Fig. 2b).

\section{Sampling design and sample processing}

To test the hypothesis that the structure of epifaunal assemblages inhabiting $S$. muticum differ between physically distinct intertidal shores, thalli of the macroalga were sampled from two sites (separated by six kilometers) under different environmental conditions on the El Jadida coastline. Sampling was conducted at low tides $(0.3-0.5 \mathrm{~m})$ on a monthly basis over a 1-year period from January to December 2015. Three random replicates (separated by $5 \mathrm{~m}$ ) per site were collected. For each replicate five individual thalli were carefully detached from the substratum, enclosed in a plastic bag,

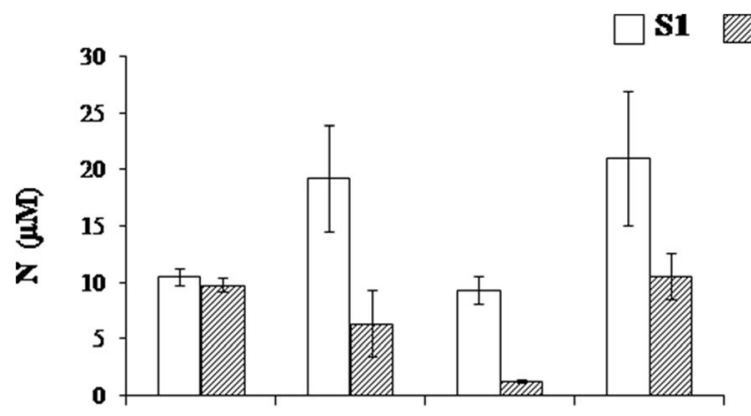

$\mathbf{S 2}$
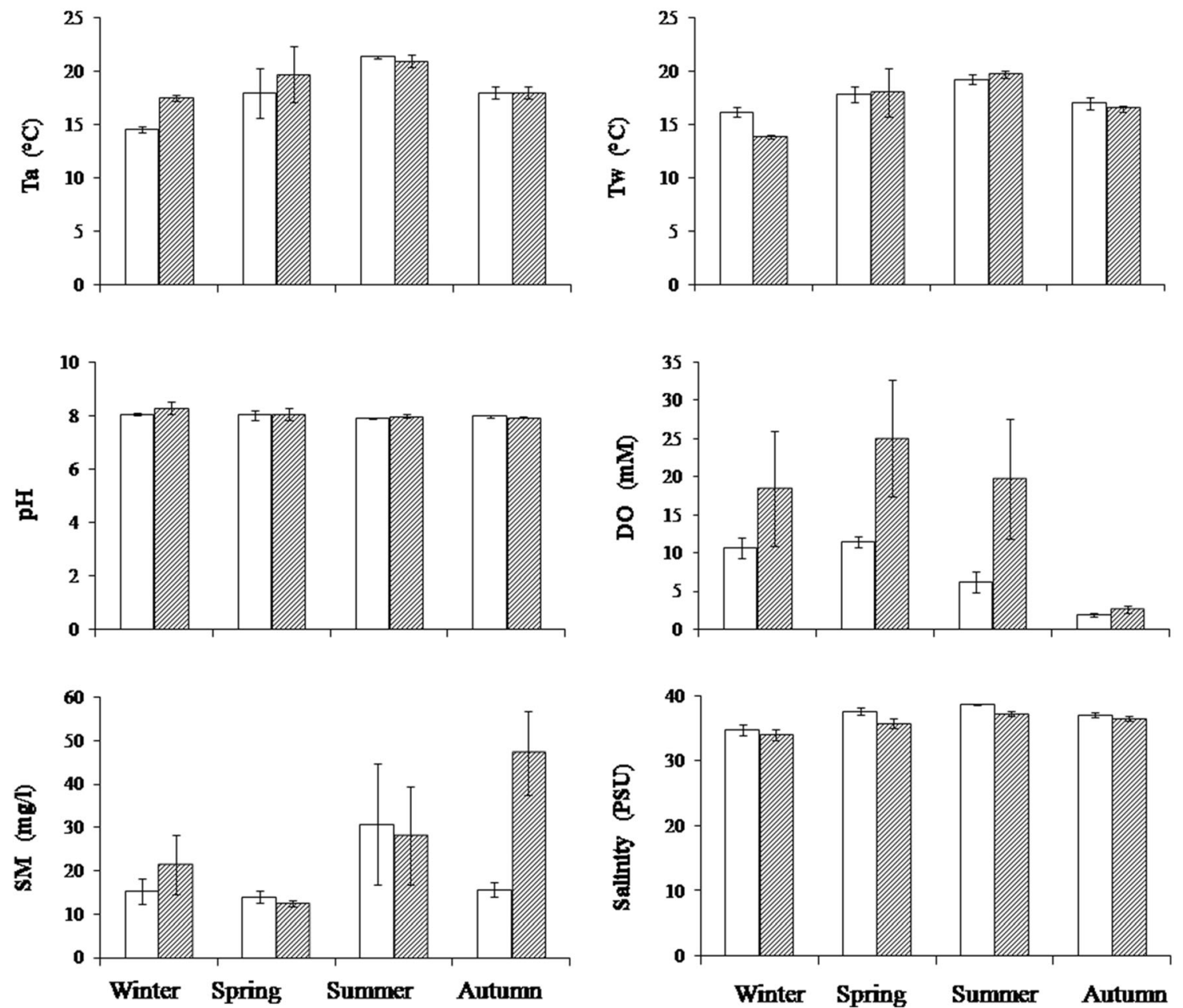

Fig. 3 Physicochemical variables measured in sites $\mathrm{S} 1$ and $\mathrm{S} 2 . \mathrm{N}$, nitrite + nitrate; $\mathrm{PO}_{4}{ }^{3-}$, orthophosphates; Ta, air temperature; Tw, water temperature; DO, dissolved oxygen; SM, suspended matter 
Table 1 Two-way ANOVA analysis testing the effect of site and season on physicochemical parameters

\begin{tabular}{|c|c|c|c|}
\hline Source of variation & df & $F$ & $p$ \\
\hline \multicolumn{4}{|c|}{ Nitrogen (nitrate + nitrite) } \\
\hline Site & 1 & 14.086 & 0.002 \\
\hline Season & 3 & 4.350 & 0.020 \\
\hline Site $\times$ season & 3 & 1.501 & 0.252 \\
\hline \multicolumn{4}{|l|}{ Orthophosphates } \\
\hline Site & 1 & 1.928 & 0.184 \\
\hline Season & 3 & 5.588 & 0.008 \\
\hline Site $\times$ season & 3 & 0.752 & 0.537 \\
\hline \multicolumn{4}{|l|}{ Air temperature } \\
\hline Site & 1 & 1.505 & 0.238 \\
\hline Season & 3 & 6.934 & 0.003 \\
\hline Site $\times$ season & 3 & 0.957 & 0.437 \\
\hline \multicolumn{4}{|l|}{ Water temperature } \\
\hline Site & 1 & 0.810 & 0.381 \\
\hline Season & 3 & 8.579 & 0.001 \\
\hline Site $\times$ season & 3 & 0.887 & 0.469 \\
\hline \multicolumn{4}{|l|}{$\mathrm{pH}$} \\
\hline Site & 1 & 0.814 & 0.373 \\
\hline Season & 3 & 1.413 & 0.276 \\
\hline Site $\times$ season & 3 & 0.415 & 0.744 \\
\hline \multicolumn{4}{|l|}{ Dissolved oxygen } \\
\hline Site & 1 & 0.810 & 0.381 \\
\hline Season & 3 & 8.579 & 0.001 \\
\hline Site $\times$ season & 3 & 0.887 & 0.469 \\
\hline \multicolumn{4}{|l|}{ Suspended matter } \\
\hline Site & 1 & 2.393 & 0.141 \\
\hline Season & 3 & 2.573 & 0.090 \\
\hline Site $\times$ season & 3 & 2.133 & 0.136 \\
\hline \multicolumn{4}{|l|}{ Salinity } \\
\hline Site & 1 & 6.688 & 0.179 \\
\hline Season & 3 & 12.995 & 0.000 \\
\hline Site $\times$ season & 3 & 0.633 & 0.605 \\
\hline
\end{tabular}

Significant $p$ values are in italics

$d f$, degree of freedom; $F$, statistic, $p, p$ value

fixed in 5\% buffered formalin-seawater solution, and brought to the laboratory for sorting. In the laboratory, each replicate was washed in tap water. The latter was subsequently sieved using a $0.5-\mathrm{mm}$ mesh screen to recover released macro-epifaunal specimens. The macroalga thalli were also examined to pick and individually remove specimens remained entangled in the algal fronds. Hereafter, all collected organisms were preserved in $70 \%$ ethanol until sorted, counted, and identified to the lowest possible taxonomic level (usually species) using a binocular stereo microscope. The thalli were dried in a stove at $60{ }^{\circ} \mathrm{C}$ for $72 \mathrm{~h}$ then weighed to measure macroalgal dry weight (DW).
The environmental variables measured during monthly sampling over the study period (January to December 2015) included air temperature (Ta), seawater temperature (Tw), salinity, $\mathrm{pH}$, dissolved oxygen (DO), nitrogen (as $\mathrm{NO}_{2}{ }^{-}$and $\mathrm{NO}_{3}{ }^{-}$), phosphates (as $\mathrm{PO}_{4}{ }^{3-}$ ), and suspended matter (SM). Ta was recorded with a stick thermometer, salinity and Tw with a WTW LF340 thermosalinometer, $\mathrm{pH}$ with a portable pHScan WP $1 / 2 \mathrm{pH}$-meter, DO with a portable HANA, and HI 9142 oxygen meter; nitrogen, phosphates, and SM analyses were made in the laboratory. Seawater samples were collected using polyethylene sampling bottles and enclosed in a coolbox at $4{ }^{\circ} \mathrm{C}$. In the laboratory, samples were filtered through Whatman ${ }^{\circledR}$ glass microfiber filters (GF/C $47 \mathrm{~mm}$ diameter, $1.2 \mu \mathrm{m}$ pore size) to assess the $\mathrm{SM}$ and to measure the nutrient contents $\left(\mathrm{NO}_{2}{ }^{-}+\right.$ $\mathrm{NO}_{3}{ }^{-}$and $\mathrm{PO}_{4}{ }^{3-}$ ) according to the methodology described by Aminot and Chaussepied (1983). Values of environmental variables were seasonally averaged.

\section{Data analysis}

Data about associated epifauna were analyzed through several univariate measures including species richness, i.e., number of taxa (S), abundance $(\mathrm{N})$, diversity (as ShannonWiener's H') (Shannon and Weaver 1963), and evenness (as Pielou's J') (Pielou 1966). All biological indices were calculated per replicate and were then rescaled to $10 \mathrm{~g}$ of macroalga dry weight.

Two-way ANOVA was applied to test for the effects of sampling site and time on the epifauna abundance, species richness and diversity, and on environmental variables considering sampling site (S1 and S2) and season (winter, spring, summer, autumn) as fixed factors. Whenever significant effects of the main factors or their interactions were found, the source of difference was identified using the pairwise comparisons based on a post hoc test (Tukey's honestly significant difference "HSD" test) set at the 5\% significance level.

Table 2 Tukey's honestly significant difference (HSD) test coupled with two-way ANOVA applied to significant effects of study site and season on physicochemical parameters

\begin{tabular}{lllllll}
\hline Seasons & $\mathrm{N}$ & $\mathrm{PO}_{4}{ }^{3}$ & $\mathrm{Ta}$ & $\mathrm{Tw}$ & $\mathrm{DO}$ & Salinity \\
& & & & & & \\
\hline Winter/spring & 0.816 & 0.544 & 0.116 & 0.027 & 0.327 & 0.006 \\
Winter/summer & 0.403 & 0.007 & 0.002 & 0.001 & 0.972 & 0.000 \\
Winter/autumn & 0.279 & 0.062 & 0.356 & 0.263 & 0.150 & 0.004 \\
Spring/summer & 0.024 & 0.100 & 0.199 & 0.343 & 0.561 & 0.175 \\
Spring/autumn & 0.750 & 0.520 & 0.892 & 0.592 & 0.005 & 0.999 \\
Summer/autumn & 0.015 & 0.697 & 0.056 & 0.038 & 0.069 & 0.220 \\
\hline
\end{tabular}

Significant $p$ values are in italics

$T a$, air temperature; $T w$, water temperature; $D O$, dissolved oxygen; $N$, nitrite + nitrate; $\mathrm{PO}_{4}{ }^{3}$, orthophosphates 
Table 3 Monthly variations in length, density, and fertility of Sargassum muticum populations in study sites

\begin{tabular}{|c|c|c|c|c|c|c|}
\hline & \multicolumn{2}{|c|}{ Thallus length $(\mathrm{cm})$} & \multicolumn{2}{|c|}{ Density (thallus $/ \mathrm{m}^{2}$ ) } & \multicolumn{2}{|c|}{ Fertility } \\
\hline & $\mathrm{S} 1$ & S2 & $\mathrm{S} 1$ & S2 & S1 & $\mathrm{S} 2$ \\
\hline January & $45.00 \pm 1.15$ & $60.00 \pm 2.08$ & $44.33 \pm 3.28$ & $21.33 \pm 1.20$ & & \\
\hline February & $51.00 \pm 2.08$ & $73.33 \pm 2.03$ & $44.00 \pm 2.08$ & $19.00 \pm 1.15$ & & \\
\hline March & $49.00 \pm 2.08$ & $131.33 \pm 3.53$ & $47.67 \pm 4.63$ & $16.33 \pm 0.33$ & $*$ & \\
\hline April & $71.00 \pm 2.08$ & $180.67 \pm 4.33$ & $44.33 \pm 0.67$ & $13.33 \pm 0.88$ & $*$ & $*$ \\
\hline May & $94.00 \pm 2.65$ & $210.00 \pm 6.08$ & $44.33 \pm 0.88$ & $10.00 \pm 0.58$ & $*$ & $*$ \\
\hline June & $113.00 \pm 4.73$ & $261.67 \pm 3.53$ & $43.00 \pm 6.24$ & $5.00 \pm 0.58$ & $*$ & $*$ \\
\hline July & $63.33 \pm 6.01$ & $53.67 \pm 7.51$ & $35.00 \pm 1.73$ & $5.00 \pm 0.58$ & $*$ & $*$ \\
\hline August & $38.67 \pm 2.73$ & $29.67 \pm 3.28$ & $23.33 \pm 0.88$ & $4.33 \pm 0.67$ & & \\
\hline September & $15.00 \pm 1.73$ & $11.00 \pm 2.08$ & $21.00 \pm 1.53$ & $3.33 \pm 0.33$ & & \\
\hline October & $11.67 \pm 0.88$ & & $24.67 \pm 1.76$ & & & \\
\hline November & $25.67 \pm 1.76$ & $21.67 \pm 2.33$ & $22.00 \pm 2.52$ & $6.67 \pm 0.33$ & & \\
\hline December & $36.00 \pm 2.65$ & $32.33 \pm 2.33$ & $25.00 \pm 0.58$ & $10.00 \pm 0.58$ & & \\
\hline
\end{tabular}

*Presence of the receptacles

Assumptions for homogeneity of variance (Levene's test) and normality (Kolmogorov-Smirnov test) were checked for prior to ANOVA analyses; and transformations were made when necessary (if the assumption to meet homogeneity failed) to remove heteroscedasticity (Underwood 1997). These statistical analyses were carried out in SPSS v11.5 software.

Differences in the epifaunal assemblage structure between both sampling sites (fixed factor: 2 levels, S1 and S2) and among seasons (fixed factor: 4 levels, winter, spring, summer, autumn) were explored using non-parametric permutational multivariate analysis of variance (PERMANOVA) (Anderson 2001; Anderson et al. 2008) on the basis of BrayCurtis similarity matrix constructed from square roottransformed data. Only significant effects $(p<0.05)$ were further investigated through a series of a posteriori multiple pairwise comparisons used to test for differences between/ within groups for pairs of levels of the selected factors (i.e., site and season). Permutational test of multivariate dispersions (PERMDISP, Anderson 2004; Anderson et al. 2008) was undertaken to check for homogeneity of dispersions between sites and among seasons. Non-metric multidimensional scaling (nMDS) analysis (Clarke and Warwick 2001) was performed to visualize on ordination plots differences in the multivariate patterns in epifaunal assemblages. The SIMPER procedure (Clarke 1993) was applied to identify the percentage contribution of each taxon and to detect species contributing mostly to the observed Bray-Curtis dissimilarities and differences revealed by PERMANOVA. In each comparison carried out, taxa were considered among the most discriminating epifauna species if their contribution to percentage dissimilarity was $\geq 5 \%$. Multivariate analyses were performed by means of PRIMER v6.1 software package (Plymouth Marine Laboratory).

\section{Results}

\section{Environmental data}

The physicochemical parameters measured in sites $\mathrm{S} 1$ and $\mathrm{S} 2$ during the study period are reported in Fig. 3. The nitrogen $\left(\mathrm{NO}_{3}{ }^{-}+\mathrm{NO}_{2}{ }^{-}\right)$values showed a significant spatiotemporal heterogeneity ( $p<0.05$; Table 1$)$ between summer and spring and between summer and autumn $(p<0.05$; Table 2$)$. In $\mathrm{S} 1$, nitrogen rate increased from winter to spring and strongly decreased in summer. In S2, nitrogen contents decreased between winter and summer, and rose in autumn (Fig. 3). Generally, waters seemed to be more concentrated in nitrogen in $\mathrm{S} 1$ compared to $\mathrm{S} 2$. The $\mathrm{PO}_{4}{ }^{3-}$ values were comparable in both sites $(p>0.05)$ but differed significantly at seasonal scale $(p<0.01)$ with a relevant increase in summer (Fig. 3). Temperatures generally exceeded $15^{\circ} \mathrm{C}$ on average in both sites, showing a clear and significant seasonal variability $(p<0.01)$ with the highest values recorded in summer $\left(\geq 20^{\circ} \mathrm{C}\right)$ (Fig. 3). The $\mathrm{pH}$ values not exceeded 8.32 (Fig. 3) indicating neither inter-season nor inter-site heterogeneity ( $p>0.05$; Table 1 ) with low standard errors not exceeding 0.1 (Fig. 3). Dissolved oxygen levels varied from 1.89 to $25.05 \mathrm{mM}$ (Fig. 3) with significant variation among seasons, particularly between spring and autumn $(p<0.01$; Tables 1 and 2 ) without any significant spatial variability $(p>0.05$; Table 1). The suspended matter did not show any clear trend within sites and no significant $(p>0.05)$ spatiotemporal heterogeneity was detected. Salinity values ranged from 34.04 to 38.69 PSU (Fig. 3) and exhibited significant ( $p<0.01$; Tables 1 and 2 ) temporal variability tending to increase during warm seasons in both studied sites. 
Table 4 Total list of macro-epifauna species associated to Sargassum muticum at the studied sites on the El Jadida shoreline

\begin{tabular}{|c|c|c|}
\hline Taxa & S1 & $\mathrm{S} 2$ \\
\hline Nemertea & + & \\
\hline \multicolumn{3}{|l|}{ Polychaeta } \\
\hline Branchiomma sp. 1 & + & \\
\hline Eulalia viridis (Linnaeus, 1767) & + & \\
\hline Eunice vittata (Delle Chiaje, 1828) & + & + \\
\hline Eupolymnia nesidensis (Delle Chiaje, 1828) & + & \\
\hline Lepidonotus clava (Montagu, 1808) & + & \\
\hline Platynereis cf. dumerilii (Audouin \& Milne Edwards, 1834) & + & + \\
\hline \multicolumn{3}{|l|}{ Mollusca Gastropda } \\
\hline Bittium reticulatum (da Costa, 1778) & + & \\
\hline Chauvetia brunnea (Donovan, 1804) & + & + \\
\hline Fusinus sp. 1 & + & \\
\hline Littorina saxatilis (Olivi, 1792) & + & + \\
\hline Melarhaphe neritoides (Linnaeus, 1758) & + & \\
\hline Mitrella alvarezi Rolán \& Luque, 2002 & + & \\
\hline Monophorus perversus (Linnaeus, 1758) & + & \\
\hline Nassarius sp. 1 & + & \\
\hline Ocinebrina sp. 1 & + & \\
\hline Omalogyra sp. 1 & + & \\
\hline Rissoa parva (da Costa, 1778) & + & + \\
\hline Steromphala pennanti (Philippi, 1846) & + & + \\
\hline Steromphala umbilicalis (da Costa, 1778) & + & + \\
\hline Tricolia pullus (Linnaeus, 1758) & + & + \\
\hline \multicolumn{3}{|l|}{ Mollusca Bivalvia } \\
\hline Musculus costulatus (Risso, 1826) & + & + \\
\hline \multicolumn{3}{|l|}{ Pycnogonida } \\
\hline Ammotheidae undetermined & + & \\
\hline \multicolumn{3}{|l|}{ Crustacea Amphipoda } \\
\hline Ampelisca lusitanica Bellan-Santini \& Marques, 1987 & + & \\
\hline Amphitholina cuniculus (Stebbing, 1874) & + & + \\
\hline Ampithoe sp. 1 & + & \\
\hline Ampithoidae undetermined & + & \\
\hline Aora spinicornis Afonso, 1976 & + & + \\
\hline Apherusa cf. ovalipes Norman \& Scott, 1906 & + & + \\
\hline Apolochus neapolitanus (Della Valle, 1893) & + & \\
\hline Calliopiidae undetermined & + & \\
\hline Caprella acanthifera Leach, 1814 & + & + \\
\hline Elasmopus vachoni Mateus \& Mateus, 1966 & + & + \\
\hline Ericthonius sp. 1 & + & \\
\hline Lysianassidae undetermined & & + \\
\hline \multicolumn{3}{|l|}{ Crustacea Isopoda } \\
\hline Cleantis sp. 1 & + & + \\
\hline Dynamene bidentata (Adams, 1800) & + & + \\
\hline Paranthura nigropunctata (Lucas, 1846) & + & \\
\hline Stenosoma cf. acuminatum Leach, 1814 & + & + \\
\hline Stenosoma cf. capito (Rathke, 1837) & + & + \\
\hline Stenosoma cf. nadejda (Rezig, 1989) & + & \\
\hline \multicolumn{3}{|l|}{ Crustacea Decapoda } \\
\hline Hippolyte varians Leach, 1814 & + & + \\
\hline Hyas cf. coarctatus Leach, 1816 & & + \\
\hline \multicolumn{3}{|l|}{ Crustacea Tanaidacea } \\
\hline Chondrochelia savignyi (Kroyer, 1842) & + & \\
\hline \multicolumn{3}{|l|}{ Echinodermata } \\
\hline Amphipholis squamata (Delle Chiaje, 1828) & + & + \\
\hline Asterina gibbosa (Pennant, 1777) & + & \\
\hline \multicolumn{3}{|l|}{ Chordata } \\
\hline Opeatogenys cadenati Briggs, 1957 & + & + \\
\hline Syngnathus acus Linnaeus, 1758 & + & \\
\hline
\end{tabular}

\section{Biological data analysis}

The monitoring of some paramertes of phenology and life cycle of the invader S. muticum in the two sites is illustrated on the Table 3. S. muticum has two distinct growth phases: the first one with a slower growth in winter followed by a second phase characterized by faster growth during springearly summer. The elongation of the thalli in S2 reached a maximum value of $261.67 \mathrm{~cm}$ in June, whereas in S1 the maximum size of the alga not exceeded $115 \mathrm{~cm}$.

S. muticum population in $\mathrm{S} 1$ showed densities ranging from 21 to 47 ind. $\mathrm{m}^{-2}$; the greatest densities were recorded during winter to early summer, subsequently, densities not exceed 25 ind. $\mathrm{m}^{-2}$ (Table 3). In S2, density values of 13-21 ind. $\mathrm{m}^{-2}$ were recorded during winter and early spring before decreasing in June (Table 3). S. muticum thalli developed receptacles on the tertiary branches earlier in S1 site (starting from March) than in S2 site (April).

A total of 48 taxa of epifauna associated with S. muticum were recovered and recorded over the duration of the sampling period (Table 4) with 21 species common to both studied sites. However, some species (i.e., the Polychaeta Eulalia viridis, Eupolymnia nesidensis, and Lepidonotus clava; the gastropods Bittium reticulatum and Monophorus perversus; the amphipods Apolochus neapolitanus and Ampelisca lusitanica; and the isopod Paranthura nigropunctata) were exclusively found in S1. The gastropods Steromphala umbilicalis (52\% of all individuals of all taxonomic groups), Rissoa parva (15\%), and Steromphala pennanti (10\%) were the most abundant associated species at the sandy site S2, while the isopod Dynamene bidentata (37\%) and the gastropods S. umbilicalis (20\%) and S. pennanti (12\%) dominated the $S$. muticum-associated epifauna communities in the site S1. D. bidentata, R. parva, S. umbilicalis, and S. pennanti exhibited seasonal changes in abundance as well as spatial discrimination between the two sites. Crustaceans and gastropods had the highest number of individuals and were the most species-rich taxonomic groups accounting for 77 and $82 \%$ of the total number of species in S1 and S2, respectively (Fig. 4).

The mean seasonal values of community structure attributes (abundance, number of species, and diversity indices $\mathrm{H}^{\prime}$ and J') of the associated epifauna at both sites are reported in the Figs. 5 and 6 . The abundance differed significantly between $\mathrm{S} 1$ and S2 $(p<0.05$; Table 5). Generally, $S$. muticum seemed to host on average more individuals in the rocky site compared to S2, particularly, during winter and spring (Fig. 5a). The number of epifaunal species associated to $S$. muticum showed comparable values between sites (Fig. 5b) with no significant differences within site and season (Fig. 5b) and no interaction effect between both factors ( $p>$ 0.05 ; Table 5). Significant spatiotemporal variability was detected for Shannon-Wiener's index $(p<0.05$; Tables 5 and 6$)$ 
a

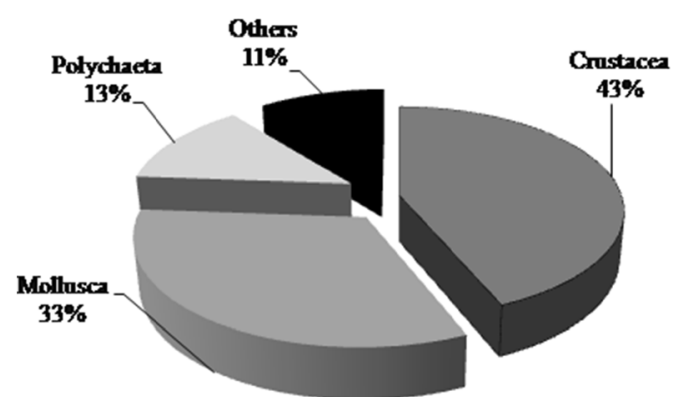

b

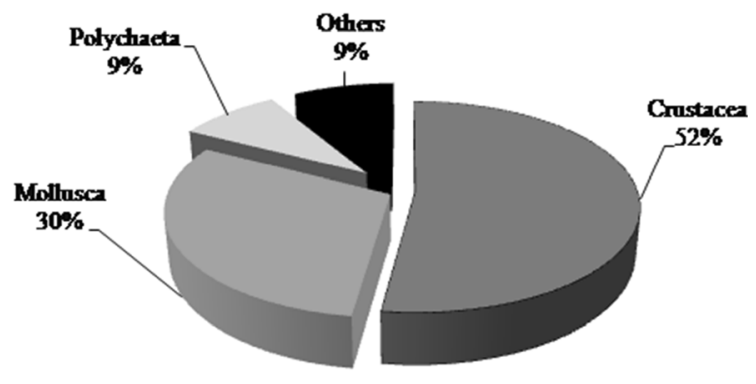

Fig. 4 Mean composition of the epifauna associated with Sargassum muticum collected from rocky site (a) and sandy site (b) along the El Jadida shoreline

with higher values in S1 than S2 (Fig. 6a). Shannon-Wiener's index showed synchronous dynamics between both sites, and exhibited the highest values during cold periods (Fig. 6a). Pielou's J' depicted similar trends on both sites (Fig. 6b) without any significant differences between sites and among seasons $(p>0.05$; Table 5).

PERMANOVA analysis pointed out significant differences in the structure of epifaunal assemblages between both sites and among seasons (Table 7). PERMDISP tests indicated no significant heterogeneity of dispersions for the factor

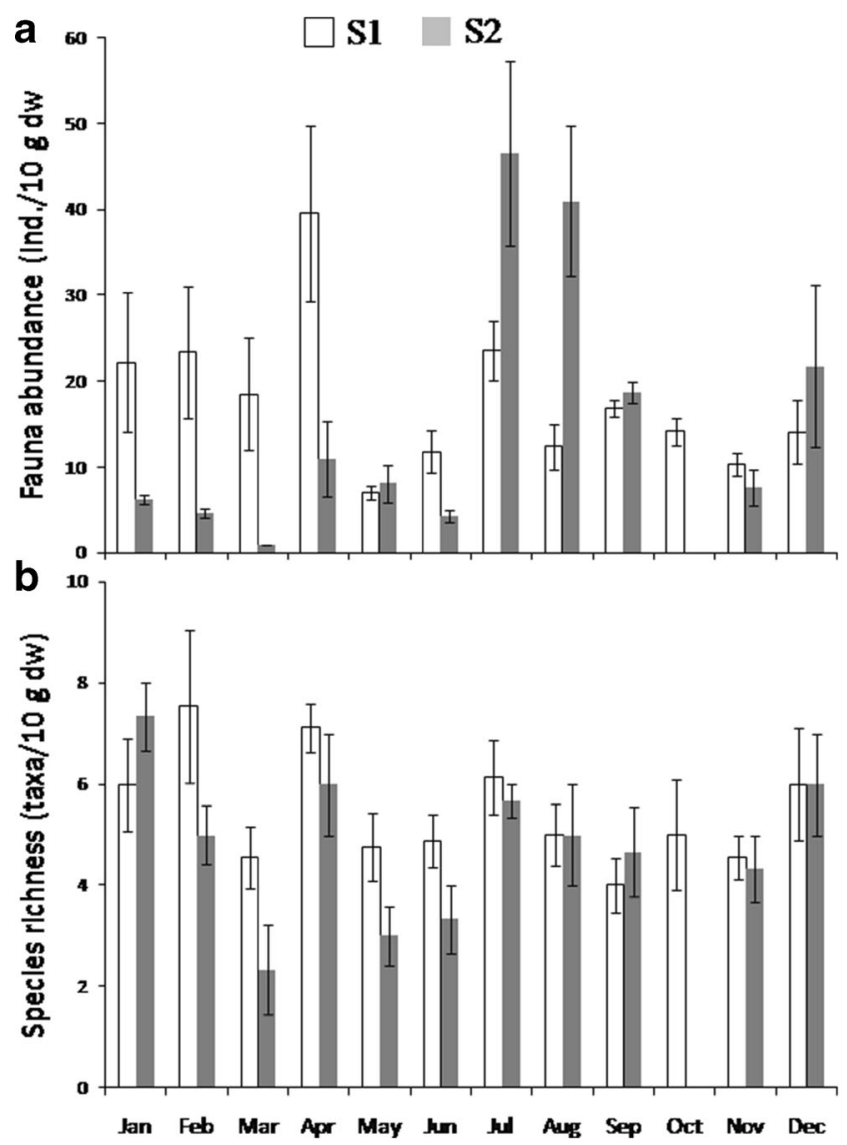

Fig. 5 Monthly variation of $\mathbf{a}$ fauna abundance and $\mathbf{b}$ species richness of the macro-epifauna associated to Sargassum muticum on site S1 (empty bars) and S2 (gray bars). Error bars represent standard errors 'site' suggesting a homogeneous dispersion between sites (PERMDISP, $F=0.046 ; P($ perm $)=0.854)$. However, there was no homogeneity of multivariate dispersion $(F=7.069 ; P$ $($ perm $)=0.001)$ in the season effect. This was essentially due to the noteworthy variation of species structure between the cold season (winter) and warm seasons (spring and summer) (PERMDISP pairwise comparisons; $P$ (perm) from 0.010 to 0.024). The two-dimensional nMDS plot (Fig. 7)
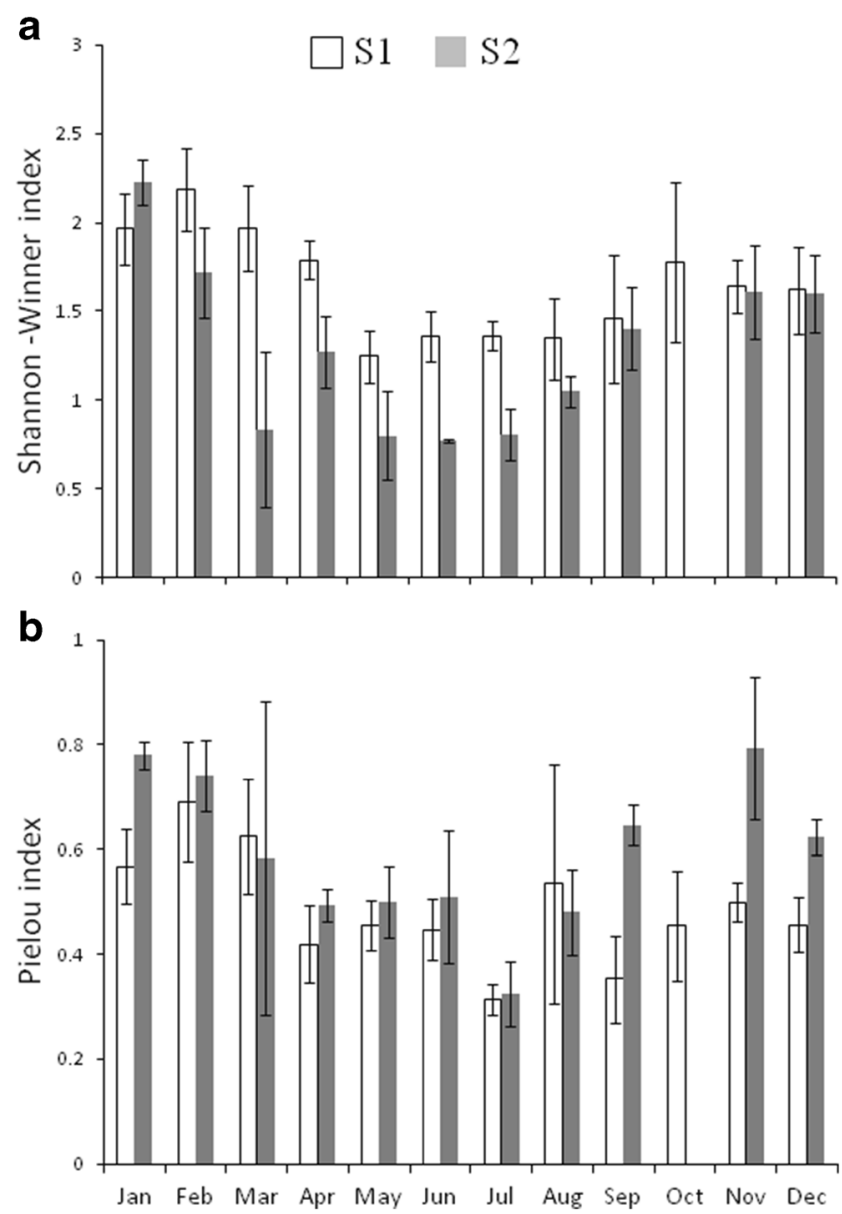

Fig. 6 Monthly variation of a Shannon-Wiener's diversity and $\mathbf{b}$ Pielou's evenness of the macro-epifauna associated to Sargassum muticum on site S1 (empty bars) and S2 (gray bars). Error bars represent standard errors 
Table 5 Two-way ANOVA analysis testing the effects of site and season on epifauna abundance, species richness, and diversity indices

\begin{tabular}{llll}
\hline Source of variation & df & $F$ & $P$ \\
\hline Abundance & & & \\
$\quad$ Site & 3 & 4.437 & 0.046 \\
Season & 3 & 0.028 & 0.993 \\
$\quad$ Site $\times$ season & & 0.229 & 0.874 \\
Species richness & 1 & & \\
Site & 3 & 0.000 & 0.997 \\
Season & 3 & 0.410 & 0.748 \\
Site $\times$ season & & 0.206 & 0.891 \\
Diversity H' index & 1 & & \\
Site & 3 & 6.180 & 0.026 \\
Season & 3 & 5.169 & 0.012 \\
Site $\times$ season & & 0.483 & 0.699 \\
Evenness J' index & 1 & & \\
$\quad$ Site & 3 & 1.074 & 0.316 \\
Season & 3 & 2.619 & 0.089 \\
Site $\times$ season & 0.406 & 0.751 \\
\hline
\end{tabular}

Significant $p$ values are in italics

$d f$, degree of freedom; $F$, statistic

corroborated the results highlighted by the PERMANOVA analysis, showing a certain discrimination between studied sites for each season. SIMPER analysis showed moderate average dissimilarities (from 58.34 to 78.53 ) between sites and seasons (Table 8 ). The isopod D. bidentata and the gastropods $S$. umbilicalis, $S$. pennanti, and $R$. parva were the most important contributive species to the observed dissimilarity of macro-epifaunal assemblages between S1 and S2 throughout all seasons. D. bidentata was more abundant in the S1 site than in S2 during all sampling seasons. Both species of the genus Steromphala showed higher abundance in S1 during spring, whereas they were represented by more individuals in $\mathrm{S} 2$ during summer. $R$. parva displayed more individuals in S2 in both summer and autumn. In general, the dissimilar distribution of species between S1 and S2 was mainly due to the variation in abundance of the most common taxa.

Table 6 Tukey's post hoc test comparaison for diversity $\mathrm{H}^{\prime}$ index

\begin{tabular}{lc}
\hline Season & $p$ values \\
\hline Winter/spring & 0.023 \\
Winter/summer & 0.032 \\
Winter/autumn & 0.820 \\
Spring/summer & 0.998 \\
Spring/autumn & 0.151 \\
Summer/autumn & 0.195 \\
\hline
\end{tabular}

Significant $p$ values are in italics

\section{Discussion}

The present paper highlights the ecological role of the introduced alga $S$. muticum by harboring abundant and diverse epifaunal assemblages, as expected for an engineer species. However, differences have been detected between the two analyzed sites with the rocky biotope (S1) hosting more diversified and abundant epibiont associations throughout seasons except for summer when the macroalga seems to support more epifaunal individuals in the sandy biotope (S2). This would be related to a slight time shift of the annual life cycle of this alga between the two sites. This shift is presumably linked to the local morphology, bottom nature, and hydrodynamism characterizing the two sampling sites. On the rocky site, the shallow rockpools limit the length and the apical growth of S. muticum thalli that are continually truncated at the growing tips of their primary axes level with the surface of the pool under the wave action. This promotes the production of lateral secondary and tertiary branches and, consequently, the earlier appearance of the receptacles (at the beginning of March). After the reproductive period, lateral branches start to degenerate in summer. On the sandy site, with water depths beyond $1 \mathrm{~m}$ at low tide, the alga undergoes its highest vegetative growth from winter to early summer with thallus lengths exceeding $2.60 \mathrm{~m}$. The elongation of thalli seems to take over the branching, causing a delay of the fertility, thus restricting the earlier degeneration of the thalli in summer.

The spatial variation of epifaunal assemblages inhabiting S. muticum along the El Jadida coast is probably linked to the degree of cover of S. muticum populations in each study site. Larger macrophyte beds are known to host greater species richness than small beds (Källén et al. 2012). It has been reported that the epifaunal diversity declines with reducing patch size of kelps, and epifaunal assemblages occurring on low-density kelp reefs are different from those recorded in high-density kelp reef (Shelamoff et al. 2019, 2020). Reasons for such variations may be related to the speciesarea relationship, linking the number of species to the surface available for colonization (Anderson 1998; Hirst and Attrill 2008; Källén et al. 2012). Alternatively, small patches can offer a refuge for species that are poorer competitors, and hence loosers in larger areas (Anderson 1998), whereas larger beds provide more microhabitats and niches, promoting colonization of several species (Anderson 1998; Hirst and Attrill 2008; Källén et al. 2012).

The $S$. muticum population is well established at the rocky site, where the alga stands maintain high densities from winter to late spring. In contrast, this alien is not able to develop dense populations on the sandy beach (S2). The low density seems caused by the detachment of the $S$. muticum's thalli feebly attached to the shallow intertidal bedrock covered with sand. Although the lenght of $S$. muticum thalli is favored by the depth of the water column, the density of this invader 
Table 7 PERMANOVA analysis testing for differences in the epifaunal assemblage structure between sites (S1 vs. S2) and seasons

\begin{tabular}{|c|c|c|c|c|c|c|c|c|}
\hline Source & & & \multicolumn{2}{|l|}{$\mathrm{df}$} & \multicolumn{2}{|c|}{ Pseudo- $F$} & \multicolumn{2}{|l|}{$P($ perm $)$} \\
\hline Site & & & \multicolumn{2}{|l|}{1} & \multicolumn{2}{|c|}{8.468} & \multicolumn{2}{|l|}{0.001} \\
\hline Season & & & \multicolumn{2}{|l|}{3} & \multicolumn{2}{|l|}{3.6864} & \multicolumn{2}{|l|}{0.001} \\
\hline Site $\times$ season & & & \multicolumn{2}{|l|}{3} & \multicolumn{2}{|l|}{2.2505} & \multicolumn{2}{|l|}{0.002} \\
\hline \multicolumn{9}{|l|}{ Pairwise tests } \\
\hline & \multicolumn{2}{|l|}{ Winter } & \multicolumn{2}{|l|}{ Spring } & \multicolumn{2}{|l|}{ Summer } & \multicolumn{2}{|l|}{ Autumn } \\
\hline & $T$ & $P($ perm $)$ & $T$ & $P($ perm $)$ & $t$ & $P($ perm $)$ & $t$ & $P($ perm $)$ \\
\hline $\mathrm{S} 1 / \mathrm{S} 2$ & 1.863 & 0.001 & 1.453 & 0.034 & 1.936 & 0.036 & 2.341 & 0.003 \\
\hline
\end{tabular}

Significant $p$ values are in italics

appears to be mainly affected by the substrate type as a forcing factor acting at local scale. This alien species commonly prefers hard substrates (Norton 1977b; North 1973; Fletcher and Fletcher 1975) but may occasionally grow on mixed substrates containing sand, gravel, and stones (den Hartog 1997). According to Thomsen et al. (2006), stones < $10 \mathrm{~cm}$ in diameter are considered as inappropriate substrates for S. muticum settlement. This alga could unsuccessfully settle on sandy substrates, where it is also prone to tissue loss produced by sand abrasion (Morrell and Farnham 1982). The establishment of a sustained vegetation cover of $S$. muticum on the studied rocky biotope could also dependent on the availability of nutrients (high nitrogen content in S1 compared to S2). In coastal ecosystems, the generally high nutrient content facilitates the establishment of invasive macroalgae (Ceccherelli and Cinelli 1997; Steen 2003; Sánchez and Fernández 2006). The spread of S. muticum in northern Spain has been modeled by the interaction between nutrient enrichment and the availability of space including the lack of native canopy algae resisting $S$. muticum establishment

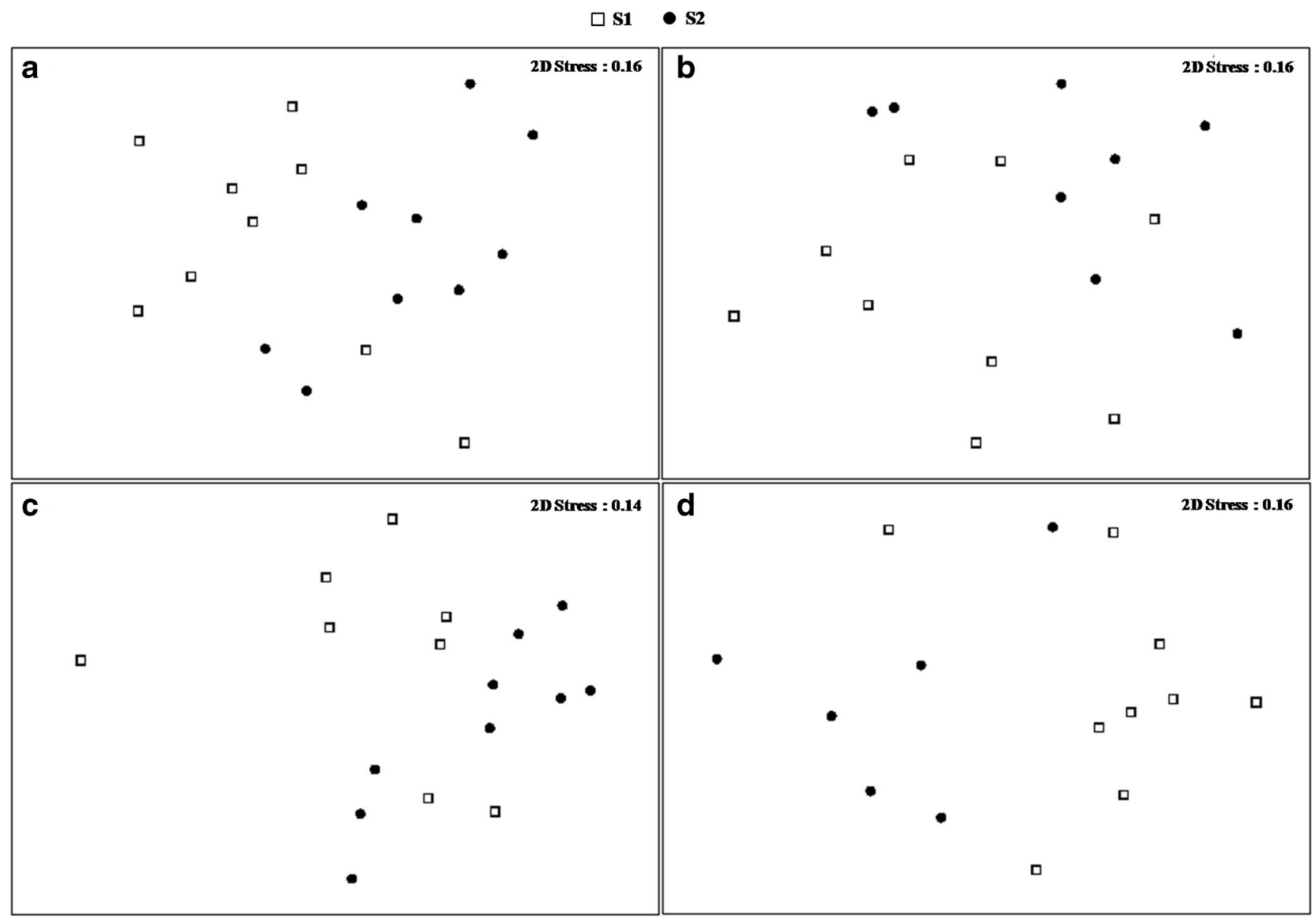

Fig. 7 Non-metric multidimensional scaling (nMDS) ordinations of macro-epifauna assemblages associated to Sargassum muticum in site S1 and S2 during winter (a), spring (b), summer (c), and autumn (d) 
Table 8 SIMPER analysis of the macro-epifauna associated to Sargassum muticum in S1 and S2 sites during sampling seasons

\begin{tabular}{|c|c|c|c|c|}
\hline Species & $\begin{array}{l}\text { S1 } \\
\text { Aver }\end{array}$ & S2 & Average Dissimilarity & Dissimilarity contribution (\%) \\
\hline \multicolumn{5}{|l|}{ Winter (75.22) } \\
\hline Dynamene bidentata & 2.66 & 0.62 & 14.56 & 19.35 \\
\hline Apherusa cf. ovalipes & 0.77 & 0.29 & 5.22 & 6.94 \\
\hline Steromphala umbilicalis & 1.07 & 0.83 & 5.09 & 6.77 \\
\hline Chauvetia brunnea & 0.60 & 0.06 & 4.74 & 6.31 \\
\hline Aora spinicornis & 0.67 & 0.00 & 4.67 & 6.21 \\
\hline Ericthonius sp. & 0.86 & 0.00 & 4.53 & 6.02 \\
\hline Steromphala pennanti & 0.66 & 0.49 & 4.52 & 6.01 \\
\hline Rissoa parva & 0.37 & 0.48 & 3.56 & 4.93 \\
\hline \multicolumn{5}{|l|}{ Spring (58.34) } \\
\hline Dynamene bidentata & 3.23 & 1.28 & 16.48 & 28.24 \\
\hline Steromphala umbilicalis & 2.44 & 1.44 & 9.86 & 16.89 \\
\hline Steromphala pennanti & 1.14 & 0.88 & 8.86 & 15.19 \\
\hline \multicolumn{5}{|l|}{ Summer (59.09) } \\
\hline Steromphala umbilicalis & 2.40 & 4.36 & 13.05 & 22.11 \\
\hline Steromphala pennanti & 0.85 & 1.51 & 7.78 & 13.19 \\
\hline Dynamene bidentata & 1.11 & 1.09 & 7.07 & 11.98 \\
\hline Rissoa parva & 0.71 & 1.04 & 5.94 & 10.06 \\
\hline Tricolia pullus & 0.00 & 0.93 & 5.19 & 8.80 \\
\hline Bittium reticulatum & 0.70 & 0.00 & 4.30 & 7.29 \\
\hline \multicolumn{5}{|l|}{ Autumn (78.53) } \\
\hline Rissoa parva & 0.00 & 2.47 & 18.17 & 23.13 \\
\hline Dynamene bidentata & 1.70 & 0.42 & 11.29 & 14.37 \\
\hline Steromphala umbilicalis & 1.15 & 1.00 & 7.79 & 9.92 \\
\hline Hippolyte varians & 0.16 & 0.81 & 6.41 & 8.16 \\
\hline Steromphala pennanti & 0.76 & 0.39 & 6.26 & 7.98 \\
\hline Opeatogenys cadenati & 0.09 & 0.64 & 4.38 & 5.58 \\
\hline
\end{tabular}

Average dissimilarities for site comparison during each season are shown in parentheses

(Sánchez and Fernández 2006). In addition, it has been reported that $S$. muticum finds a refugium in wave-protected tide pools and that it cannot develop under severe hydrodynamic conditions (Andrew and Viejo 1998b). In exposed locations, strong wave action causes plant fragmentation and populations are unable to recover to their former ecological stage in such locations (Viejo et al. 1995). Consequently, the hydrodynamic conditions and the absence of a suitable substratum could also be regarded as a limiting factor for S. muticum occurrence in the sandy site.

The structure of the macro-epifauna associated with S. muticum differed significantly between the two study sites. Similar results have been highlighted by Buschbaum et al. (2006) who reported how the community structure and species composition associated to $S$. muticum varied significantly between a rocky shore of the island of Helgoland and a soft sediment environment near the island of Sylt (North Sea, German Bight). The spatial distribution of epifaunal communities is influenced not only by the algae as habitat but also by the hydrodynamic conditions of the environment (Guerra-García et al. 2011). Several studies have revealed major differences in the epiphytic invertebrate composition on various species of macroalgae across gradients of wave exposure (e.g., Beckley and McLachlan 1979; Tararam and Wakabara 1981; Edgar 1983; Moore 1972, 1985; DeFelice and Parrish 2001). Taxonomic richness, abundance, and diversity of invertebrate assemblages showed significant negative relationships with exposure to wave energy at Hanalei Bay, Kauai, Hawaii (DeFelice and Parrish 2001). In this study, the presence of rocky pools and breakwater structures in $\mathrm{S} 1$ provide protection to thalli and their associated organisms from wave action. This could partly explain the relatively high epifauna diversity recorded from this site. The substratum type, otherwise, would not be considered a forcing/key factor for the spatial patterns of the epifauna composition associated to $S$. muticum along the El Jadida coastline. Some species found exclusively within the shallow rocky pools in S1 were previously recorded in sandy and/or muddy biotopes (Watson 1886; Marques and Bellan-Santini 1987; Martínez et al. 2007; Scipione and Zupo 2010). 
S. muticum is a pseudo-perennial alga. Thus, associated epifaunal assemblages are lost after the natural detachment of the lateral branches in late summer. An annual recolonisation of the alga is necessary because only a few species remain attached to the basal fixation system, maintaining their presence during winter (Norton and Benson 1983; Jephson and Gray 1977; Buschbaum et al. 2006). Therefore, recolonisation of $S$. muticum by the epifaunal organisms could be potentially ruled by other macroalgal species present at each study sites. Actually, most of algal species colonizing the site S1 (mainly represented by the brown algae belonging to Fucales, Dictyotales, Sphacelariales, Laminariales, and Tilopteridales, and some red algae belonging to Gelidiales, Gigartinales, and Gracilariales) are absent from the site S2 which is characterized by the dominance of red algae (Rhodymeniales, Ceramiales, Gigartinales, Gracilariales, Halymeniales, Plocamiales, and Nemaliales) with only some species of brown algae (mainly Dictyotales) and green algae (Bryopsidales).

The selection of seaweed hosts by marine invertebrate epifauna based on internal (such as cell structure and cell wall components, energetic storage products, and defensive biochemistry) and external features (morphology) of seaweeds; yet, thallus form has been shown to be a stronger regulator of invertebrate epifauna than palatability or defensive chemistry (Dean and Connell 1987; Norderhaug 2004).

The observations of invertebrate richness across algal morphology, generally, tend to follow common perceptions about relationships between algal thallus complexity and invertebrate diversity (Chemello and Milazzo 2002; Bates 2009; Veiga et al. 2014). Specifically, the complexly branching corticated algae in S1 (like Cystoseira humilis, C. tamariscifolia, Fucus guiryi, Sargassum vulgare, Gelidium pulchelum, and Gelidium spinulosum) could have the most associated invertebrates providing a more diverse source for the annual recolonisation of $S$. muticum, whereas algae with simple morphology in S2 (like Grateloupia lanceola, Laurencia obtusa, Osmundea pinnatifida, Gymnogongrus patens, Codium decorticatum, and C. tomentosum) could host the fewest associated invertebrates.

In conclusion, the present investigation revealed that the macro-epifauna associated with the invasive $S$. muticum is more diverse and abundant in the rocky site than in the sandy site throughout seasons except for summer. Furthermore, the structure of epifaunal assemblages associated with this alien macroalga differed significantly between the two study sites. The orientation of the shoreline, the topographic and bottom morphology, and the type of substrate of each beach in addition to the hydrodynamic factors (waves, swells, currents) and the local occurrence of anthropogenic artifacts seem to influence the establishment and the development of S. muticum, generating a shift in the life cycle (growth, reproduction, and degeneration periods) between the two sites. This determines, albeit indirectly, the spatiotemporal variability in composition and abundance of the associated macro-epifauna.

Acknowledgements The authors are grateful to the anonymous reviewers for providing useful comments and suggestions that improved the manuscript.

\section{Compliance with ethical standards}

Conflict of interest The authors declare that they have no conflict of interest.

Ethical approval All applicable international, national, and/or institutional guidelines for the care and use of animals were followed.

\section{References}

Aminot A, Chaussepied M (1983) Manuel des analyses chimiques en milieu marin. CNEXO, Brest

Anderson MJ (1998) Effects of patch size on colonisation in estuaries: revisiting the species-area relationship. Oecologia 118:87-98

Anderson MJ (2001) A new method for non-parametric multivariate analysis of variance. Austral Ecol 26:32-46

Anderson MJ (2004) PERMDISP: a FORTRAN computer program for permutational analysis of multivariate dispersions (for any twofactor ANOVA design) using permutation tests. University of Auckland, Auckland

Anderson MJ, Gorley RN, Clarke KR (2008) PERMANOVA+ for PRIMER: guide to software and statistical methods. PRIMER-E, Plymouth

Andrew NL, Viejo RM (1998a) Effects of wave exposure and intraspecific density on the growth and survivorship of Sargassum muticum (Sargassaceae: Phaeophyta). Eur J Phycol 33:251-258

Andrew NL, Viejo RM (1998b) Ecological limits to the invasion of Sargassum muticum in northern Spain. Aquat Bot 60:251-263

Bates CR (2009) Host taxonomic relatedness and functional-group affiliation as predictors of seaweed-invertebrate epifaunal associations. Mar Ecol Prog Ser 387:125-136

Beckley LE, McLachlan A (1979) Studies on the littoral seaweed epifauna of St. Croix Island. I. Physical and biological features of the littoral zone. S Afr J Zool 14(4):175-182

Bedini R, Bedini M, Bonechi L, Piazzi L (2015) Effects of non-native turf-forming Rhodophyta on mobile macro-invertebrate assemblages in the north-western Mediterranean Sea. Mar Biol Res 11(4):430-437

Belattmania Z, Chaouti A, Reani A, Machado M, Engelen AH, Serrão EA, Sabour B (2018a) Similar epiphytic macrofauna inhabiting non-native Sargassum muticum and native fucoids on the Atlantic coast of Morocco. Cryptogam Algol 39(3):269-292

Belattmania Z, Chaouti A, Reani A, Engelen AH, Machado M, Serrão EA, Sabour B (2018b) The introduction of Sargassum muticum modifies epifaunal patterns in a Moroccan seagrass meadow. Mar Ecol 39:e12507

Bertness MD, Leonard GH, Levine JM, Schmidt PR, Ingraham AO (1999) Testing the relative contribution of positive and negative interactions in intertidal communities. Ecology 80(8):2711-2726

Bolam SG, Eggleton J, Smith R, Mason C, Vanstaen K, Rees H (2008) Spatial distribution of macrofaunal R. assemblages along the English Channel. J Mar Biol Assoc UK 88(4):675-687

Bremner J, Rogers SI, Frid CLJ (2006) Matching biological traits to environmental conditions in marine benthic ecosystems. J Mar Syst 60:302-316 
Buschbaum C, Chapman AS, Saier B (2006) How an introduced seaweed can affect epibiota diversity in different coastal systems. Mar Biol 148:743-754

Buschmann AH (1990) Intertidal macroalgae as refuge and food for amphipoda in Central Chile. Aquat Bot 36:237-245

Cacabelos E, Olabarria C, Incera M, Troncoso JS (2010) Effects of habitat structure and tidal height on epifaunal assemblages associated with macroalgae. Estuar Coast Shelf Sci 89:43-52

Ceccherelli G, Cinelli F (1997) Short-term effects of nutrient enrichment of the sediment and interactions between the seagrass Cymodocea nodosa and the introduced green alga Caulerpa taxifolia in a Mediterranean bay. J Exp Mar Biol Ecol 217:65-177

Chemello R, Milazzo M (2002) Effect of algal architecture on associated fauna: some evidence from phytal mollusks. Mar Biol 140:981-990

Clarke KR (1993) Non-parametric multivariate analyses of changes in community structure. Aust J Ecol 18:117-143

Clarke KR, Warwick RM (2001) Change in marine communities:an approach to statistical analysis and interpretation. PRIMER-E, Plymouth

Critchley AT (1983) The establishment and increase of Sargassum muticum (Yendo) Fensholt populations within the Solent area of southern Britain. I. An investigation of the increase in number of population individuals. Bot Mar 26:539-545

Critchley AT, Farnham WF, Morrell SL (1983) A chronology of new European sites of attachment for the invasive brown alga. Sargassum muticum, 1973-1981. J Mar Biol Assoc UK 63:799-811

Curiel D, Bellemo G, Marzocchi M, Scattolin M, Parisi G (1998) Distribution of introduced Japanese macroalgae Undaria pinnatifida. Sargassum muticum (Phaeophyta) and Antithamnion pectinatum (Rhodophyta) in the Lagoon of Venice. Hydrobiologia 385:17-22

Dean RL, Connell JH (1987) Marine invertebrates in algal succession. II. Tests of hypotheses to explain diversity with succession. J Exp Mar Biol Ecol 109:217-247

Defelice RC, Parrish JD (2001) Physical processes dominate in shaping invertebrate assemblages in reef-associated sediments of an exposed Hawaiian coast. Mar Ecol Prog Ser 215:121-131

Den Hartog C (1997) Is Sargassum muticum a threat to eelgrass beds? Aquat Bot 58:37-41

Edgar GJ (1983) The ecology of south-east Tasmanian phytal animal communities. I Spatial organization on a local scale. J Exp Mar Biol Ecol 70:129-157

Ellison AM, Bank MS, Clinton BD, Colburn EA, Elliott K, Ford CR, Foster DR, Kloeppel BD, Knoepp JD, Lovett GM, Mohan J, Orwig DA, Rodenhouse NL, Sobczak WV, Stinson KA, Stone JK, Swan CM, Thompson J, Von Holle B, Webste JR (2005) Loss of foundation species: consequences for the structure and dynamics of forested ecosystems. Front Ecol Environ 3(9):479-486

Engelen AH, Primo AL, Cruz T, Santos R (2013) Faunal differences between the invasive brown macroalga Sargassum muticum and competing native macroalgae. Biol Invasions 15:171-183

Engelen AH, Serebryakova A, Ang P, Britton-Simmons K, Mineur F, Pedersen MF, Arenas F, Fernández C, Steen H, Svenson R, Pavia H, Toth G, Viard F, Santos R (2015) Circumglobal invasion by the brown seaweed Sargassum muticum. Oceanogr Mar Biol 53:81126

Fernández E, Fernández C, Anadón R (1990) Variacion estacional de las poblaciones de moluscos y crustaceos del horizonte de Gelidium latifolium (Grev.) Born. et Thur. de la costa central de Asturias. Rev Biol Univ Oviedo 8:85-89

Fletcher RL, Fletcher SM (1975) Studies on the recently introduced brown alga Sargassum muticum (Yendo) Fensholt. I Ecology and reproduction. Bot Mar 18(3):149-156

Fredriksen S, Christie H, Sæthre BA (2005) Species richness in macroalgae and macrofauna assemblages on Fucus serratus L. (Phaeophyceae) and Zostera marina L. (Angiospermae) in Skagerrak, Norway. Mar Biol Res 1:2-19
Giberto DA, Bremec CS, Acha EM, Mianzan H (2004) Large-scale spatial patterns of benthic assemblages in the SW Atlantic: the Rio de la Plata estuary and adjacent shelf waters. Estuar Coast Shelf Sci 61:1-13

Gray JS (2001) Antarctic marine benthic biodiversity in a world-wide latitudinal context. Polar Biol 24:633-641

Guerra-García JM, Baeza Rojano E, Cabezas MP, García Gómez JC (2011) Spatial patterns and seasonal fluctuations of intertidal macroalgal assemblages from Tarifa Island, Southern Spain: relationship with associated Crustacea. J Mar Biol Assoc UK 91:107111

Guerra-García JM, Ros M, Izquierdo D, Soler-Hurtado MM (2012) The invasive Asparagopsis armata versus the native Corallina elongata: differences in associated peracarid assemblages. J Exp Mar Biol Ecol 416-417:121-128

Hales JM, Fletcher RL (1989) Studies on the recently introduced brown alga Sargassum muticum (Yendo) Fensholt. IV. The effect of temperature, irradiance and salinity on germling growth. Bot Mar 32: $167-176$

Harries DB, Harrow S, Wilson JR, Mair JM, Donnan DW (2007) The establishment of the invasive alga Sargassum muticum on the west coast of Scotland: a preliminary assessment of community effects. J Mar Biol Assoc UK 87:1057-1067

Hicks GRF (1980) Structure of phytal harpacticoid copepod assemblages and the influence of habitat complexity and turbidity. J Exp Mar Biol Ecol 44:157-192

Hirst JA, Attrill MJ (2008) Small is beautiful: an inverted view of habitat fragmentation in seagrass beds. Estuar Coast Shelf Sci 78:811e818

Jephson NA, Gray PWG (1977) Aspects of the ecology of Sargassum muticum (Yendo) Fensholt in the Solent Region of the British Isles. 1. The growth cycle and epiphytes. In: Keegan BF, Boaden PJS, Ceidigh PO (eds) Biology of Benthic Organisms. 11th European Symposium on Marine Biology. Pergamon Press, Oxford, pp 367-375

Jones E, Thornber CS (2010) Effects of habitat-modifying invasive macroalgae onepiphytic algal communities. Mar Ecol Prog Ser 400:87-100

Källén J, Muller H, Franken ML, Crisp A, Stroh C, Pillay D, Lawrence C (2012) Seagrass-epifauna relationships in a temperate south African estuary: interplay between patch-size, within-patch location and algal fouling. Estuar Coast Shelf Sci 113:213-220

Labrune C, Gremare A, Amoroux JM, Sarda R, Gil J, Taboada S (2007) Asssessment of soft-bottom polychaete assemblages in the Gulf of Lions (NW Mediterranean) based on a mesoscale survey. Estuar Coast Shelf Sci 71(1-2):133-147

Marques JC, Bellan-Santini D (1987) Crustacés Amphipodes des côtes du Portugal: faune de l'estuaire du Mira (Alentejo. côte sud-ouest). Cah Biol Mar 28(3):465-480

Martínez J, Adarraga I, Ruiz JM (2007) Tipificación de poblaciones bentónicas de los fondos blandos de la plataforma continental de Guipúzcoa (Sureste del golfo de Vizcaya). Bol Inst Esp Oceanogr 23(1-4):85-110

Metzger JR, Konar B, Edwards MS (2019) Assessing a macroalgal foundation species: community variation with shifting algal assemblages. Mar Biol 166:156

Moore PG (1972) The kelp fauna of northeast Britain. I Introduction and physical environment. J Exp Mar Biol Ecol 13:97-125

Moore PG (1985) Levels of heterogeneity and the amphipod fauna of kelp holdfasts. In: Moore PG, Seed R (eds) The ecology of rocky coasts. Hodder and Stoughton, London, pp 274-289

Morrell SL, Farnham WF (1982) Some effects of substratum on Sargassum muticum. Br Phycol J 17:236-237

Mueller R, Fischer AM, Bolch CJS, Wright JT (2015) Environmental correlates of phenotypic variation: do variable tidal regimes influence morphology in intertidal seaweeds? J Phycol 51:859-871 
Norderhaug KM (2004) Use of red algae as hosts by kelp-associated amphipods. Mar Biol 144:225-230

North WJ (1973) Regulating marine transplantation. Science 179(4079): 1181

Norton TA (1976) Why is Sargassum muticum so invasive? Br Phycol J 11:197-198

Norton TA (1977a) Ecological experiments with Sargassum muticum. J Mar Biol Assoc UK 57:33-43

Norton TA (1977b) The growth and development of Sargassum muticum (Yendo) Fensholt. J Exp Mar Biol Ecol 26:41-53

Norton TA, Benson MR (1983) Ecological interactions between the brown seaweed Sargassum muticum and its associated fauna. Mar Biol 75:169-177

Pielou EC (1966) Shannon's formula as a measure of specific diversity: its use and measure. Am Nat 100:463-465

Ramus AP, Silliman BR, Thomsen MS, Long ZT (2017) An invasive foundation species enhances multifunctionality in a coastal ecosystem. PNAS 114(32):8580-8585

Sabour B, Reani A, EL Magouri H, Haroun R (2013) Sargassum muticum (Yendo) Fensholt (Fucales. Phaeophyta) in Morocco, an invasive marine species new to the Atlantic coast of Africa. Aquat Invasions 8(1):97-102

Sánchez I, Fernández C (2006) Resource availability and invasibility in an intertidal macroalgal assemblage. Mar Ecol Prog Ser 313:85-94

Schaffelke B, Hewitt CL (2007) Impact of introduced seaweeds. Bot Mar 50:397-417

Scipione MB, Zupo V (2010) Crustacean amphipods from the seagrasses Zostera marina, Cymodocea nodosa and Posidonia oceanica in the Adriatic Sea (Italy): a first comparison. Zool Baetica 21:15-32

Shannon C, Weaver W (1963) The mathematical theory of communication. University Illinois Press, Urbana

Shelamoff V, Layton C, Tatsumi M, Cameron MJ, Wright JT, Johnson CR (2019) Patch size and density of canopy-forming kelp modify influences of ecosystem engineering on understorey algal and sessile invertebrate assemblages. Mar Ecol Prog Ser 632:59-79

Shelamoff V, Layton C, Tatsumi M, Cameron MJ, Edgar GJ, Wright JT, Johnson CR (2020) Kelp patch size and density influence secondary productivity and diversity of epifauna. Oikos 129(3):331-345

Smith JR (2016) The putative impacts of the non-native seaweed Sargassum muticum on native communities in tidepools of Southern California and investigation into the feasibility of local eradication. Mar Ecol 37:645-667

Stachowicz JJ (2001) Mutualism, facilitation, and the structure of ecological communities. Bioscience 51:235-246

Steen H (2003) Intraspecific competition in Sargassum muticum (Phaeophyceae) germlings under various density, nutrient and temperature regimes. Bot Mar 46:36-43
Tararam AS, Wakabara Y (1981) The mobile fauna - especially Gammaridea - of Sargassum cymosum. Mar Ecol Prog Ser 5: $157-163$

Taylor RB (1998) Seasonal variation in assemblages of mobile epifauna inhabiting three subtidal brown seaweeds in northeastern New Zealand. Hydrobiologia 361:25-35

Thomsen MS (2010) Experimental evidence for positive effects of invasive seaweed on native invertebrates via habitat-formation in a seagrass bed. Aquat Invasions 5(4):341-346

Thomsen MS, Wernberg T, Stæhr PA, Pedersen MF (2006) Spatiotemporal distribution patterns of the invasive macroalga Sargassum muticum within a Danish Sargassum-bed. Helgol Mar Res 60:50-58

Thomsen MS, Stæhr PA, Nejrup L, Schiel DR (2013) Effects of the invasive macroalgae Gracilaria vermiculophylla on two cooccurring foundation species and associated invertebrates. Aquat Invasions 8(2): 133-145

Umanzor S, Ladah L, Calderon-Aguilera LE, Zertuche-González JA (2017) Intertidal macroalgae influence macroinvertebrate distribution across stress scenarios. Mar Ecol Prog Ser 584:67-77

Underwood AJ (1997) Experiments in ecology: their logical design and interpretation using analysis of variance. Cambridge University Press, Cambridge

Veiga P, Rubal M, Sousa-Pinto I (2014) Structural complexity of macroalgae influences epifaunal assemblages associated with native and invasive species. Mar Environ Res 101:115-123

Viejo RM (1997) The effects of colonization by Sargassum muticum on tidepool macroalgal assemblages. J Mar Biol Assoc UK 77:325-340

Viejo RM, Arrontes J, Andrew NL (1995) An experimental evaluation of the effect of wave action on the distribution of Sargassum muticum in northern Spain. Bot Mar 38:437-444

Ware C, Dijkstra JA, Mello K, Stevens A, O'Brien B, Ikedo W (2019) A novel three dimensional analysis of functional-architecture that describes the properties of macroalgae as refuge. Mar Ecol Prog Ser 608:93-103

Watson RB (1886) Report on the Scaphopoda and Gasteropoda collected by H.M.S. challenger during the years 1873-1876. Zoology 15: $1-761$

Wernberg T, Thomsen MS, Stæhr PA, Pedersen MF (2004) Epibiota communities of the introduced and indigenous macroalgal relatives Sargassum muticum and Halidrys siliquosa in Limfjorden (Denmark). Helgol Mar Res 58:154-161

Wikström SA, Kautsky L (2004) Invasion of a habitat-forming seaweed: effects on associated biota. Biol Invasions 6:141-150

Publisher's note Springer Nature remains neutral with regard to jurisdictional claims in published maps and institutional affiliations. 